\section{International Scientific Journal Theoretical \& Applied Science}

\author{
p-ISSN: 2308-4944 (print) e-ISSN: 2409-0085 (online) \\ Year: $2014 \quad$ Issue: 12 Volume: 20 \\ Published: $30.12 .2014 \quad$ http://www.T-Science.org
}

\author{
EInur Latif oglu Hasanov \\ Corresponding member of International Academy of \\ Theoretical and Applied Sciences, \\ Ph.D. postgraduate \\ Institute of Local-lore of Ganja Branch \\ Azerbaijan National Academy of Sciences, \\ Ganja, Azerbaijan \\ 1-hasan@hotmail.com
}

SECTION 12. Geology. Anthropology. Archaeology.

\title{
TO THE QUESTION ON THE RESEARCH OF TYPICAL FEATURES OF CRAFTSMANSHIP HERITAGE OF GANJA OF THE LATE XIX - EARLY XX CENTURIES
}

\begin{abstract}
In scientific work for the first time in this work were systematic investigated the basic skill characteristics of different wares of handicraft branches of Ganja and its significance in research of artistic craftsmanship traditions. This scientific article deals with the historic-ethnographical importance of development of the main traditional branches of craftsmanship of Ganja. In Ganja internal conditions of craft department reflected a sort of employment of his owner. In these departments worked the master and his pupils. In a life of the population of Ganja the role of craft products was great. These products were widely used inhabitants of Ganja they decorated conditions of living rooms, with them filled up a dowry of brides. The dresses created in local departments, suits and caps were an integral part of an attire of town-dwellers. It also has been bundled to accruing arrival to Ganja representatives of other nationalities. Therefore changes in clothes were more marked. Only female ornaments as an attire constituent part left the national feature. At this time there were fashionable ornaments on a breast, hands, set pins and on clothes. The increase in quantity of handicraftsmen in a city directly has been bundled to population growth.

The competition of production of production plants and factories has not reached still serious level and consequently was created a favorable condition for spreading of traditional occupations there. In addition, products of these craft branches have been closely bundled to a life and traditions of the people, and it would be difficult to replace with their factory production. In the specified period of history in Ganja developed basically carpet weaving, weaver's business, craft of the tailor, squeeze men, forge and a jeweler, trades of dyer, the stone mason, the cooper and leather dresser, weapon business and other similar craft branches. Traditional spheres of crafts are invaluable and reliable sources of studying of culture, aesthetic taste, outlook, world outlook, of the Azerbaijan people.

Key words: Ganja, Azerbaijan, handicraft traditions, ethno-anthropological investigation, XIX-XX centuries.

Language: English

Citation: Hasanov EL (2014) TO THE QUESTION ON THE RESEARCH OF TYPICAL FEATURES OF CRAFTSMANSHIP HERITAGE OF GANJA OF THE LATE XIX - EARLY XX CENTURIES. ISJ Theoretical \& Applied Science 12 (20): 27-30. doi: http://dx.doi.org/10.15863/TAS.2014.12.20.7
\end{abstract}

\section{Introduction}

Investigation of the main traditional craft branches on the basis of new, innovative methods and technologies is very important. Results of these researches show the significance of different patterns of craftsmanship kinds as a source in studying of historical past of nations. The increase in quantity of handicraftsmen in a city directly has been bundled to population growth. The competition of production of production plants and factories has not reached still serious level and consequently was created a favorable condition for spreading of traditional occupations there. In addition, products of these craft branches have been closely bundled to a life and traditions of the people, and it would be difficult to replace with their factory production. In the specified period of history in Ganja developed basically carpet weaving, weaver's business, craft of the tailor, squeeze men, forge and a jeweler, trades of dyer, the stone mason, the cooper and leather dresser, weapon business and other similar craft branches (Guliyeva $\mathrm{N}$ and Häsänov E, 2014).

Among these crafts especially developed carpet weaving. To so wide development of carpet weaving promoted availability of raw materials. In addition carpets were very widely used in a population life- 
both as furniture, and as a curtain, both as sand bed and as a coating for a floor. In carpet weaving have been held basically women. It has been bundled by that in a Muslim society of the woman preferred to work in house conditions. However also know cases when men were occupied with this craft (Taylor P and Hasanov E, 2013). Tailors and hatters created both national clothes, and clothes in style of the European fashion. According to the spent explorations there are exact data on wide development of a jeweler in Ganja in the end of XIX century - in a beginning of XX centuries. Jewelers basically fabricated ornaments to order. Among them there was a specification. Jobs of skilful masters amazed even foreigners. Development of trading and economic relations of Ganja with the next states promoted recognition of local jewels abroad. In middle ages in spheres of gentle and applied art, Ganja of inhabitants of territory, in agriculture life bone was widely applied. Bone products, raw materials, that found during investigations in and around Ganja prove that time bone processing separated from other spheres of craftsmanship. These samples of art make more ancient history of city culture of Azerbaijan and in whole play nard. There were found knife handles, rare geometrical decorations, samples of pipe and other instruments here. During excavations there was found bone products that used as raw materials and cutting with pipe.

In this ancient city printed cotton and calico fabrics have been widely produced. In traditional cloth productions the main place took the urban mines. The majority of these artists were weaving. In Ganja, which was the most important center of cloth production were produced different kinds of cotton cloth. In general, in Ganja from textile there were made cotton cloth with simple painting, various kinds' decorations. In most cases, in the XIX-XX centuries after coarse calico colored in white colors of, it colored to different colors. History and art of Azerbaijan people as rich and colorful as its nature (Ohmodov F, 2007). On decorations of this descriptive art are reflected spiritual world, living style, customs and traditions of our nation. These pearls of art on material preparing and processing techniques are divided into different kinds. Among these types of craft metal treatment is mostly developed and has ancient history. Abundance of local raw materials created favorable conditions for development of metal treatment from ancient times. In general, in the third millennium $\mathrm{BC}$ there was high culture of the Bronze Age in our country, and in the first millennium transition period from Bronze Age to Iron Age began. In that period in Azerbaijan there were appeared several branches of metallurgy treatment. Jewelries, daggers, arms, copper products and other samples of art have been treated so refined, that in nowadays they are protected as very valuable exhibits in famous museums. Scientific and archaeological researches have proved that Ganja had been the cradle of science and culture not only of Azerbaijan, but also of the whole East.

\section{Materials and methods}

Traditional spheres of crafts are invaluable and reliable sources of studying of culture, aesthetic taste, outlook of the Azerbaijan people. Ethnographic and anthropologic exploration of problems and branches of crafts very important, as a way of studying along with history and culture of the people, years generated political-economical and relations of production. From the investigated national employment carpet weaving, the jeweler, a stone dressing and strenuously develop on the basis of ancient traditions already dying out ancient trades, such as a pottery and an art embroidery. Each area of Azerbaijan possesses characteristic environmental resource bases for it and it promoted development of various crafts. Thus, a number of employments in Ganja, during the period since XIX century to the middle of XX century, differed from crafts of other areas of the country (Ofəndiyev R, 1966; Guliyeva N and Häsänov E, 2014).

During our scientific investigations about research of local craftsmanship traditions of Ganja have been used some main innovative academic methods:

1. Investigation of importance of the handicraft patterns as the main source in research of characteristics of formation and development of Urban culture (formation process of the features of urban culture) on the basis of scientific arguments;

2. Research of local materials of craftsmanship patterns;

3. Determination of traditional methods and materials of handicraft wares on the basis of innovative roads;

4. For the first time research of problem of genesis of handicraft traditions on the basis of production technology and technique of local craftsmanship patterns;

5. Foundation of the new scientific direction on ethnography and ethnology on the basis of investigation of sustainable historical features of handicraft branches in research of the historical past of formation and development of Urban culture.

During 2012-2014 with application of new scientific approaches, also innovative technologies have been determined by us some new results about handicraft heritage of Ganja.

\section{Results and discussion}

It was first of all the trades bundled to a spreading of a city and population grown has 
increased demand for craft products. Under such circumstances the handicraft work could not keep the natural character. Already in a number of branches finished articles have been exposed on a market. Ganja is one of the richest areas from archaeological point of view. Investigation of traditional wares of handicraft kinds of Ganja on the basis of innovative methods is very important and necessary. As a result of ethno-archaeological investigations here were found samples of material culture that concerned to the stages of different history period. Today most of them are kept in various museums of the world. Archaeological investigations prove that in this period the main population of this region had sedentary lifestyle and were engaged with farming. Works of art, made from metal, for their content and their form are divided into two major groups. They are products of art and household goods.

Since the time of the early Middle Ages, Ganja as other big cities has been the main center of Azerbaijan in production of cotton cloth. In this ancient city printed cotton and calico fabrics have been widely produced. In traditional cloth productions the main place took the urban mines.

From the construction point of view, samples of pottery, that concern to Antique period, also to the period of Hellenism in Ganja, differed in various forms as pictorial vases, ceramic figures, connected dishes. During the end of Middle Ages and New Period in Ganja and its regions ceramic has following kinds as building ceramic materials, unglazed ceramic products, glazed ceramic products. For Middle Ages and New period among pottery products of Ganja ceramic samples as clay construction materials have great importance. First of all, glazed bricks that used in construction of most buildings in the XVII-XVIII centuries, and also in great monuments and the main construction material - air-dried bricks, attracted attention. In addition to the found samples in residential areas as a result of archaeological excavations, also were found a lot of brick spoilages. According to such kind mass finding of brick spoilages, we can make the conclusion, that the bricks used in construction of buildings in Ganja, were wares of local production (Azarbaycan etnoqrafiyasl, 2007; Nishiaki Y and Hasanov E, 2014).
The formation of pottery on the territory of ancient Ganja is concern to the stages of ancient history. Basis on research works carried out by the various persons in XIX century and expertsarcheologists at the beginning of XX century in old ruins of the city and surrounding areas there were found different samples of pottery.

\section{Conclusions}

a) As in many places, production of wool, cotton and silk in and around Ganja made necessary emergence and development of weaving. In the first half of the XVIII-XIX centuries, as well as in other parts of Azerbaijan, in Ganja household objects, forging weapons and jewelries that made from metal were decorated with different technical ways.

b) Becoming weaving one of the ancient spheres of crafts in and around Ganja was connected with the rich raw material base here. Presence of useful plant species for textile, including cotton, high level development of wool area of agriculture-sheep and goat breeding, camel breeding, horse breeding, presence of cotton cropping in Middle Ages and finally, regular expansion of silkworm breeding in this area created a foundation for growth of weaving here.

c) In traditional production of cloth manufactory trade historically played an important place. This kind of craft that developed on the basis of local raw materials was tied with cottongrowing economy (Taylor $\mathrm{P}$ and Hasanov $\mathrm{E}$, 2013).

d) Internal conditions of craft department reflected a sort of employment of his owner. In these departments worked the master and his pupils. In a life of the population of Ganja the role of craft products was great. The dresses created in local departments, suits and caps were an integral part of an attire of town-dwellers.

e) In comparison with villages though the national clothes in XX century began to supersede them gradually. It also has been bundled to accruing arrival to Ganja representatives of other nationalities. Therefore changes in clothes were more marked. Only female ornaments as an attire constituent part left the national feature.

References:

1. Azarbaycan etnoqrafiyası (2007) 3 cilddə, I c., Bakı: Şərq-Qərb. 544.

2. Azarbaycan tarixi üzro qaynaqlar (1989) Bakı: Azərbaycan Universiteti nəşriyyatı. 328.

3. Bünyadova ST (1992) Nizami vo etnoqrafiya. Bakı: Elm.
4. Burton-Brown $\mathrm{T}$ (1951) Excavations in Azerbaijan, 1948. London.

5. Ohmədov FM (2007) Gəncənin tarix yaddaşı. Gəncə: Elm.

6. Ofəndiyev RS (1966) Azarbaycanın badii sənətkarlı̆̆l. Bakı: Azərnəşr. 
7. Guliyeva NM, Häsänov EL (2014) Die traditionelle Gändschänischen Teppiche von Zeitraum der Aserbaidschanischen Gelehrten und Dichter Mirsä Schäfi Waseh als ethnoanthropologische quelle (XIX Jahrhundert). European Applied Sciences, 2: 3-5.

8. Hasanov EL (2013) About fundamental studies on local cultural traditions of Ganja. European Journal of Natural History, 3: 65-68.

9. Hasanov EL (2014) Approccio innovativo per lo studio scientifico delle tradizioni artigianali grandi Ganja seconda metà del XIX-inizi XX secolo. Italian Science Review, 4: 642-645.

10. Həmidova İ (2000) Azərbaycan parça sənətinin tarixi inkişaf yolları. Elmi axtarışlar, VIII toplu, Bakı.
11. Həvilov HA (1991) Azarbaycan etnoqrafiyast. Bakı: Elm.

12. Nishiaki Y, Hasanov EL (2014) About ethnoarchaeological and anthropological research of some prehistoric monuments of Ganja. ISJ Theoretical \& Applied Science, 01 (9): 45-48. doi:

http://dx.doi.org/10.15863/TAS.2014.01.9.8

13. Taylor PM, Hasanov EL (2013) Ethnological features of cultural heritage of Ganja (On the basis of Mahsati Ganjavi's creation). ISJ Theoretical \& Applied Science, 12 (8): 41-44. doi:

http://dx.doi.org/10.15863/TAS.2013.12.8.10

14. Tərlanov M, Ofəndiyev R (1960) Azarbaycan xalq sənəti. Bakı: Uşaq gənc nəşr. 